\title{
A KÖZOKTATÁS REFORMJA ÉS AZ OKTATÁSI RENDSZER IRÁNTI BIZALOM
}

\author{
KOPASZ MARIANNA* - BODA ZSOLT
}

MTA Társadalomtudományi Kutatóközpont

\begin{abstract}
A cikkben az oktatási rendszer iránti bizalommal foglalkozunk, mégpedig a 2010-es magyarországi kormányváltást követően elindított átfogó közoktatási reform kapcsán. Írásunkban nyomon követjük az oktatási rendszer iránti bizalom alakulását a közpolitikai folyamat során, a reform előkészítésétől a megvalósításig. Azt vizsgáljuk, hogy milyen tényezők eredményezhették az állampolgárok oktatási rendszer iránti bizalmának olyan mértékü gyengülését, amely a közpolitikai folyamat előrehaladásával egyre nagyobb számban vezetett tiltakozásokhoz. Amellett érvelünk, hogy az oktatási rendszerbe vetett bizalom hanyatlásában szerepet játszott mind az általa nyújtott közszolgáltatás színvonalának a közvélekedésben is megjelenő romlása, mind pedig maga a közoktatás átfogó megújítását célzó közpolitikai folyamat, amely nem volt képes sem a szakszerűség, sem a méltányos eljárás képzetét kialakítani az érintettekben.
\end{abstract}

Kulcsszavak: közpolitikai reform, bizalom, közoktatás, megvalósítás, méltányosság, kompetencia

The article focuses on trust in the education system in relation to the educational reform launched by the newly formed government after the 2010 parliamentary elections in Hungary. Trust in the education system will be examined throughout the policy process - from conception to implementation. We will focus on the factors that are supposed to have led to the erosion of trust in the education system which was manifest in the growing number of demonstrations with the advancement of the policy process. We argue that both the declining quality of education and the policy process itself (which failed to make the impression of competence and procedural fairness) have contributed to the erosion of trust in the education system.

Keywords: policy change, trust, education, implementation, fairness, competence

\footnotetext{
* Levelező szerző: Kopasz Marianna, MTA Társadalomtudományi Kutatóközpont, 1097 Budapest, Tóth Kálmán u. 4. E-mail: Kopasz.Marianna@tk.mta.hu
} 


\section{Bevezető}

$\mathrm{A}$ kutatók és szakpolitikusok jó ideje hangsúlyozzák az oktatási rendszerek fejlett országokban megfigyelhető egyre növekvő komplexitását (lásd pl. Halász 2006), ami többek között a rohamosan terjedő és gyorsan változó információ- és kommunikációtechnológiának, az oktatás fokozódó nemzetközivé válásának, a stakeholderek egyre jobban differenciálódó igényeinek, valamint a decentralizáltabb és rugalmasabb irányítási rendszereknek köszönhető (Fazekas-Burns 2012; Cerna 2014). Az ilyen komplex rendszerek müködéséhez, és különösen ezeknek a reformjához, elengedhetetlen a bizalom megléte (Puranam-Vanneste 2009; idézi Cerna 2014). Ugyanakkor a komplex rendszerekben nehezebb a bizalom megteremtése és erősítése a stakeholderek nagy száma és a köztük lévő folyamatosan változó interakciók miatt (Cerna 2014).

A z oktatási rendszer iránti bizalom kérdései mindazonáltal ez idáig nem részesültek kiemelt figyelemben az intézményi bizalommal foglalkozó irodalmon belül. A kevés kivétel között megemlítendő az OECD 2011-ben indult „Governing Complex Education Systems" (GCES) projektje, amely a komplex oktatási rendszerek irányításának hatékony modelljeit állította a középpontba. A kutatás záró, 2015-16-os fázisában a központi kérdések közé beemelték a bizalom oktatásirányításban játszott szerepének vizsgálatát. Az oktatási rendszerbe vetett bizalom kiépülésének, fennmaradásának és helyreállításának stratégiái köré 2015-ben Hágában „Trust and Education” címmel konferenciát szerveztek, amit az „Education Governance in Action” címü kötet megjelenése is követett (OECD 2016). A kötet esettanulmányai alapján az a következtetés vonható le, hogy a világos és koherens oktatáspolitikai stratégia megléte, az érintettek bevonása a döntéshozatalba, valamint a releváns közpolitikai szereplők autonómiájának és kapacitásának erősítése növeli a reformba vetett bizalmat és az intézkedések végrehajtásának hatékonyságát.

Ebben a cikkben az oktatási rendszer iránti bizalommal foglalkozunk, mégpedig a 2010-es magyarországi kormányváltást követően elindított átfogó közoktatási reform kapcsán. A cikkben azt a kérdést járjuk körül, hogy milyen tényezők eredményezhették az állampolgárok oktatási rendszer iránti bizalmának olyan mértékű gyengülését, amely a közpolitikai folyamat során egyre nagyobb számban vezetett tiltakozásokhoz, s amely megmutatkozik a Gallup World Poll OECD-tagországokban végzett felmérésének intézményi bizalomra vonatkozó adataiban is. Amellett fogunk érvelni, hogy az oktatási rendszerbe vetett bizalom eróziójában az általa nyújtott közszolgáltatás színvonalának romlása mellett szerepet játszott a közoktatás átfogó megújítását célzó közpolitikai folyamat maga is, amely nem volt képes sem a szakszerűség, sem a méltányos eljárás képzetét kialakítani az érintettekben. Az oktatási rendszer iránti bizalom alakulását az alábbiakban nyomon követjük a közpolitikai folyamat szakaszain, a reform elökészítésétől a megvalósításig.

Elemzésünk esettanulmány, amely nyilvánosan elérhető felmérések adatai, közpolitikai dokumentumok és a sajtóban megjelent információk alapján rekonstruálja a hazai közoktatási reform folyamatát, és ezzel kapcsolatban az érintettek és az állampolgárok attitüdjeit. Kutatásunk feltáró jellegü, amely ugyan a leíráson túllépve oksági feltételezéseket is megfogalmaz az intézményi bizalom szakirodalma és elméletei alapján, ám a feltevések tesztelésére az alkalmazott eljárás nem nyújt lehetőséget, és további kutatást tesz szükségessé. Összefoglalva megállapítható, hogy a magyar eset alátámasztani látszik azon téziseket, amelyek egyfelől a kompetencia, illetve a méltányos eljárások fontosságát 
emelik ki a bizalom kialakításában, másfelől kapcsolatot látnak a bizalom és a közpolitikai reformok eredményessége között.

\section{Az intézményi bizalomról}

Vizsgálódásunk az állampolgárok intézmények iránti bizalmára irányul, azon belül is az oktatási rendszerbe és kisebb részben a nemzeti kormányba vetett bizalomra. Az intézményi bizalomnak nincs széles körű konszenzuson nyugvó meghatározása, de ez elmondható magával a bizalom fogalmával összefüggésben is. Cerna (2014) bizalomdefiníciója - melyet az OECD 2016-os oktatásirányítással foglalkozó publikációja is átvett - a bizalom három elemét hangsúlyozza: a bizalom egyrészt várakozás, másrészt arra vonatkozó hajlandóság, hogy magunkat általa sebezhetővé tegyük, harmadrészt pedig kockázatvállaló cselekvés. Ebben az írásban, törekedve az egyszerüségre, a bizalom fogalmát Gambetta (1988: 217) nyomán mint azt a várakozást ragadjuk meg, hogy a másik fél számunkra üdvös, de legalábbis nem hátrányos módon fog eljárni. Hozzá kell tennünk azt is: a bizalom fogalma feltételezi, hogy a másik fél rendelkezik annak szabadságával, hogy ne feleljen meg ennek a várakozásnak (hiszen különben nem volna szükség a bizalom megelőlegezésére). Ebben az értelmezésben a bizalom a bizonytalanság csökkentésének eszköze (vö. Luhmann 1988). Érdemesnek látszik Barber (1983) alapján különbséget tenni a bizalom két komponense között. Az egyik összetevő a másik fél kompetenciája iránti bizalom. Az intézményekbe vetett bizalommal illusztrálva: az a várakozás, hogy az adott intézmény szakszerűen, kompetensen, eredményesen végzi el feladatait, illetve a közpolitikai beavatkozást kidolgozó és végrehajtó szereplők rendelkeznek a szükséges tudással és tapasztalattal az eredményes reform végrehajtására. A másik komponens ugyanakkor azzal a várakozással függ össze, hogy az intézmények, közpolitikai szereplők a közjó érdekében járnak el, nem pedig partikuláris érdekek vagy morálisan megkérdőjelezhető célok mentén. A közjóval kapcsolatos percepciók mindig vitathatóak, ám Tom Tyler sokat idézett műve óta (1990) általánosan elfogadott, hogy az emberek empirikusan jól kimutatható érzékenysége az eljárásokkal, a procedúrák méltányosságával kapcsolatban a közjó iránti elkötelezettséggel is magyarázható (vö. Smith et al. 2007). Egyszerüen fogalmazva: az emberek a vezetők magatartását a döntések meghozatala során a közjó indikátorának használják. Ha a döntés részvételen, mérlegelésen, az érintettek meghallgatásán alapul; ha pártatlan és elfogulatlan; ha respektust fejez ki az érintettek felé, akkor növeli a bizalmat. Az eljárási méltányosság elveinek sérülése viszont a bizalmatlanságot erősíti.

A bizalomnak minden helyzetben van egy optimális szintje. Ez alatt azt a szintet értjük, amely elérhetővé teszi a bizalom megelőlegezése révén megszerezhető hasznokat, de közben ugyanakkor védelmet nyújt a bizalommal való visszaéléssel és a szükségtelen kockázatvállalással szemben. Az egészségügy iránti bizalom túl alacsony szintje a közszolgáltatások túlzott igénybevételét és az erőforrások hatékonytalan allokációját eredményezheti. Ilyen esetben például a páciensek kevésbé hajlandók az orvosi elöírások betartására, és gyakrabban járnak orvosról orvosra (Van der Schee et al. 2007; idézi OECD 2016). A túl nagy bizalom ugyanígy veszélyeket hordoz magában. A bizalmi helyzetre építve gyakran fordul elő a hatalommal való visszaélés (Warren 1999; idézi OECD 2016). A túlzott bizalom ugyanis elaltathatja az éberséget, vagyis a bizalmat megelőlegező fél eltekint a monitorozástól (OECD 2016). 
Amilyen nehéz a bizalmat kiépíteni, olyan könnyü lerombolni (Dasgupta 1988: 50). A bizalom könnyen veszélybe kerülhet válság idején, vagy ha reformra kerül sor, mivel ezek bizonytalanságot keltenek a stakeholderekben az őket érintő következményeket illetően. A közpolitikai folyamat során a bizalom összeomlása gyakorlatilag bármikor bekövetkezhet, de különösképpen a változás lényegének, céljának meg- vagy épp félreértése, a várható kimenetek, illetőleg a folyamat sikerességének értékelése kapcsán (Ford-Ford 1995; OECD 2016).

Bouckaert (2012) szerint a kormányba vetett bizalom három szinten is elemezhető. Makroszinten a kormány iránti bizalom a politikai intézményekhez és a demokratikus múködéshez köthető. Mezoszinten a bizalom a kormányzatnak a közpolitikák megalkotása terén mutatott képességével függ össze. Végül, mikroszinten ahhoz a hatáshoz kapcsolódik, amelyet a kormány gyakorol a közszolgáltatások nyújtása révén az állampolgárok mindennapi életére (OECD 2013a: 28). Amint az OECD 2013-as „Government at a Glance” címü kiadványa rámutat, Bouckaert (2012) taxonómiája két szempontból is figyelemre méltó. Egyfelől, a kormány iránti bizalom nem olyan valami, ami csak úgy megtörténik a kormánnyal, hanem épp ellenkezőleg, a kormány nagyon is befolyásolhatja azt tevékenysége és a közpolitikák révén. Másfelől, amikor a közpolitikák bizalmat formáló hatásáról beszélünk, nemcsak azok végeredménye az, ami számít, hanem maga a közpolitika-alkotás és megvalósítás folyamata is (OECD 2013a: 28), vagyis az, hogy ezek a folyamatok képesek-e a szakszerüség és a méltányosság (közjó) képzetének létrehozására az érintettek körében. Ebben az írásban mi is abból indulunk ki, hogy az oktatási rendszer iránti bizalom formálódásában szerepe van mind az oktatásügyi reformok megalkotásának és implementációjának, mind pedig a közpolitikai folyamat kimenetének.

Mi a jelentősége a bizalomnak? A legfontosabb, hogy a bizalom az intézményi müködés, illetve a közpolitika legitimitásának indikátora, és mint ilyen az együttmüködési hajlandóság jelzője (vö. Boda 2013). A bizalom ekképpen a közpolitikák és az intézmények eredményességét is befolyásolja (OECD 2013a). Magasabb bizalomszint mellett az állampolgárok inkább hajlandóak elfogadni a kockázatos vagy költséges döntéseket (Györffy 2012; Hetherington 2005); betartani a törvényeket és együttmúködni az állami intézményekkel (Tyler 1990) - vagyis az Albert O. Hirschman (1995) által „hüségnek” nevezett stratégiát választani még akkor is, ha érzékelnek bizonyos problémákat. Az alacsony bizalomszint viszont csökkenti a bizonytalanságtürést és a költségek elviselésének hajlandóságát, és könnyen bekapcsol a „tiltakozás” vagy a „kivonulás” stratégiája. Különböző módon, de mindkettő veszélyezteti az eredményes közpolitikai működést. A tiltakozás ellenállást jelent, míg a kivonulás alternatívák keresését: például a rendőrségbe és az igazságszolgáltatásba vetett bizalom gyengülése privát (személyi testőr, biztonsági felszerelés stb.) vagy akár törvényen kívüli (önbíráskodás, maffia) megoldások kereséséhez vezethet.

\section{A kormány és az oktatási rendszer iránti bizalom alakulása Magyarországon}

A Gallup World Poll (GWP) adatai szerint a kormány iránti bizalom Magyarországon a 2008-as mélypontot követően jelentős növekedést mutatott 2011-ig (lásd 1. ábra). Abban az évben az állampolgárok 36\%-a nyilatkozott úgy, hogy megbízik a kormányban. Ez a bizalomerősödés figyelemre méltó lehet, mivel a válság az OECD-tagállamok többségében a nemzeti kormányok iránti bizalom megrendülését vonta maga után eb- 


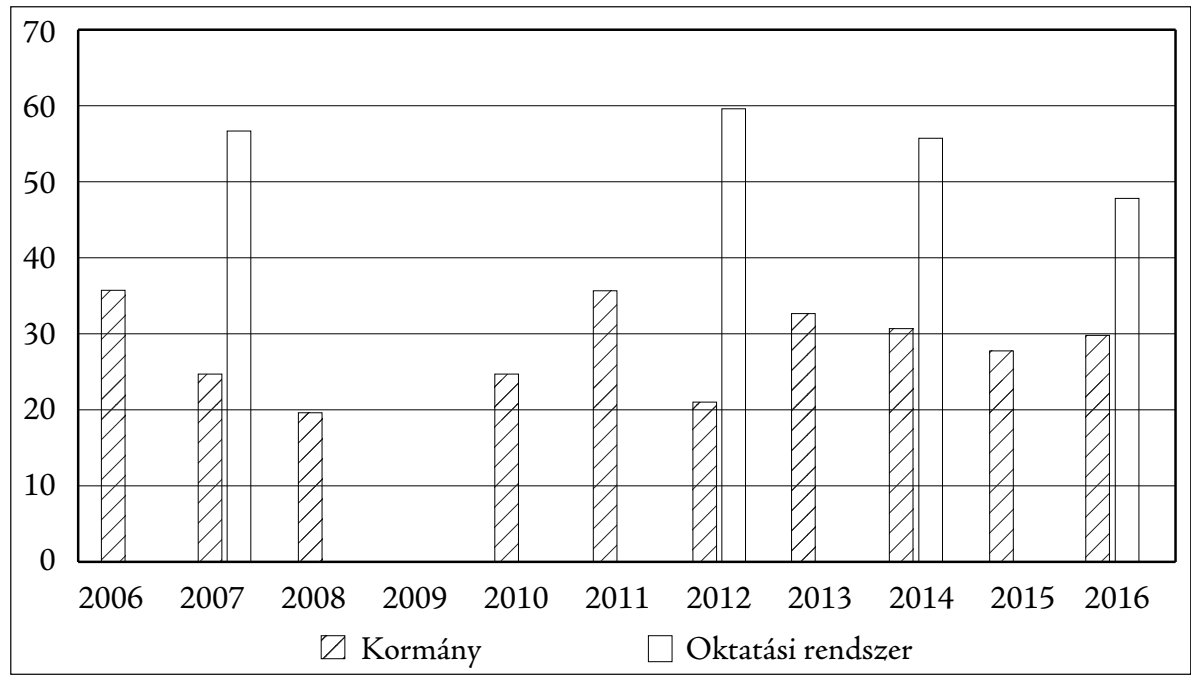

1. ábra: A nemzeti kormány és az oktatási rendszer iránti bizalom Magyarországon a Gallup World Poll adatai alapján (2006-2016). (Forrás: saját szerkesztés az OECD Government at a Glance adatbázis adatai alapján.)

ben az időszakban. Tekintetbe kell azonban venni, hogy Magyarországon a GWP 2011es hullámának felvétele nem sokkal a 2010-es kormányváltást követően zajlott, vagyis olyan időszakban, amikor jellemzően erősödik a bizalom. A kormányok jellemzően ilyenkor vágnak bele a politikailag megosztóbb, jelentős újraelosztással járó reformokba (Hetherington 2005). Így az újonnan hivatalba lépő - kétharmados parlamenti többséggel rendelkező - kormány az oktatási rendszer megújítását előirányzó nagyszabású reformot a lehető legkedvezőbb pillanatban indította el. A kormány iránti megnövekedett bizalom azonban, ahogyan az ábrán is látszik, nem tartott sokáig: 2012-ben erősen visszaesett (21\%), és azóta sem érte el a kormányváltáskor tapasztalt szintet (2016-ban 30\% volt).

Nem teljesen világos azonban, hogy vajon pontosan mire is gondolhatnak az állampolgárok, amikor a kormányzatba vetett bizalomról faggatják őket a felmérések során. Egy 2013-as OECD-kiadvány arra a következtésre jut a GWP adatainak elemzése alapján, hogy amikor a kérdezettek a kormányzat iránti bizalmukról nyilatkoznak, akkor elsősorban az ország vezetéséről alkotnak véleményt és kevésbé a közszolgáltatások nyújtásáról és a közpolitika-alkotásként értett kormányzásról (OECD 2013a). Az azonban megint csak nyitott kérdés, hogy az ország vezetésébe beleértik-e az államigazgatás felsőbb szintjeit is, vagy csak a politikai vezetést (OECD 2013a).

A GWP különböző hullámai alapján jól látszik, hogy az állampolgárok a kormánynál tendenciájában jobban megbíznak a konkrét közszolgáltatásokban, mint amilyen az egészségügy, a helyi rendőrség, az oktatás, vagy az igazságszolgáltatás. ${ }^{1} \mathrm{~A} z$ oktatási rendszer iránti bizalom mérésére - az intézményi bizalommal foglalkozó irodalommal összhangban - proxyként a felmérésnek azt a kérdését használjuk, hogy a kérdezett elé-

1 Ezt megerősítik az Eurobarometer felmérésből származó adatok is. 
gedett-e az oktatási rendszerrel vagy iskolákkal azon a településen, ahol él. ${ }^{2}$ Megjegyezzük azonban, hogy a bizalom és az elégedettség fogalma nem teljesen fedi le egymást: míg a bizalom definíciójában explicite megjelenik a jövőre orientáltság, addig az elégedettség fogalmában nem. Ugyanakkor a bizalom mint önmegerősítő folyamat nem független a múltbeli tapasztalatoktól; a korábbi interakciók során szerzett pozitív tapasztalatok (elégedettség) a bizalom jövőbeli megelőlegezését vonják maguk után.

Az oktatási rendszer iránti bizalomra vonatkozóan sajnos csak 2007-re, illetve 2012től kezdődően kétévente állnak rendelkezésre adatok (az OECD Government at a Glance adatbázisából ${ }^{3}$ ). A GWP adatai szerint Magyarországon az oktatási rendszer iránti bizalom 2012-től egyértelmü gyengülést mutat. Míg abban az évben még az állampolgárok 60\%-a, addig 2016-ban már csak 48\%-uk bízott az oktatási rendszerben. Ez nemcsak hogy alatta marad az OECD-átlagnak, hanem egyben azt is jelzi, hogy nálunk kevésbé már csak a görögök bíznak az oktatási rendszerükben az európai OECD-tagállamok közül.

Láttuk tehát, hogy a közoktatási reform elfogadása óta Magyarországon fokozatosan gyengül az oktatási rendszerbe vetett bizalom. Nézzük most a két intézményibizalom indikátor alakulását egymással összevetve is! A 2012-es év a kormányváltás utáni első olyan év, amikorra vonatkozóan vannak adataink mind a kormány iránti, mind pedig az oktatási rendszer iránti bizalomra. Ezek azt mutatják, hogy az oktatási reform végrehajtásának kezdetén - ami egy-két korrekciós lépést leszámítva csak 2013-ra tehető - a nemzeti kormány iránti bizalom nagyon alacsony szintjéhez mérten az oktatási rendszerben relatíve sokan bíztak (21\% szemben a 60\%-kal). 2016-ra ezzel szemben magasabb kormányba vetett bizalomhoz igen alacsony oktatási rendszer iránti bizalom társul (30\% és 48\%).

A fenti adatok alapján is kézenfekvőnek tünik, hogy kapcsolatot feltételezzünk a kormány 2010-ben elindított átfogó oktatási reformja és az oktatási rendszer iránti bizalom 2012-től megfigyelhető gyengülése között. Egy ilyen oksági összefüggést természetesen csak valószínúsíthetünk. Mindazonáltal érdemesnek tünik alaposabban is szemügyre venni, hogy a társadalom tagjainak oktatási rendszer iránti bizalma - beleértve annak mindkét fentebb körülírt komponensét - hogyan, milyen tényezőknek köszönhetően csökkenhetett az oktatás megújítására irányuló közpolitikai folyamat során.

\section{A z oktatási rendszerbe vetett bizalom eróziója a közoktatás reformja során}

A közoktatás megújításának igénye a 2010-es kormányváltást követően lényegében előzmények nélkül került fel a közpolitikai napirendre, mégpedig oly módon, hogy elmaradt a reform érdemi indoklása, a főbb célok megjelölése. A közoktatás reformja iránti bizalom a közpolitikai folyamat során lépésről lépésre erodálódott. Mint látni fogjuk, már a törvény koncepciójának előkészítését is az információkhoz való hozzáférés nehezítése, az érdekelteknek a közpolitikai folyamattól való távoltartása jellemezte - ami nem felel meg a méltányos eljárás feltételeinek. Az oktatásirányítás iránt a reform előrehaladásával fokozatosan növekvő bizalmatlanság a törvény elfogadása, majd implementációja során

2 Ennél a kérdésnél sem lehetünk abban biztosak, hogy a válaszadók az elégedettségük mérlegelésekor a helyi iskolára gondolnak, vagy figyelembe veszik a rendszer egészét, beleértve az oktatásért felelős minisztériumot is (Cerna 2014: 37).

3 https://stats.oecd.org/Index.aspx?QueryId=78406 [Letöltve: 2018. 10. 25.] 
tetőzött. Az alábbiakban alaposabban is körüljárjuk a bizalmat gyengítő tényezőket a közpolitikai folyamat szakaszai mentén haladva (már amennyire lehetséges a szakaszok azonosítása e konkrét közpolitikai beavatkozás kapcsán). Megállapításaink elsősorban a választási programok, a kormányprogram, a médiában megjelent nyilatkozatok, illetve beszédek elemzésére épülnek. A közoktatási reform tartalmi elemeinek ismertetésétől ehelyütt eltekintünk, és figyelmünket a közpolitikai folyamatra irányítjuk.

\section{A reform közpolitikai napirendre kerülése}

Bár a közoktatás fennálló rendszerében köztudottan voltak megoldásra váró problémák, a kormányprogram (Nemzeti Együttmüködés 2010) nem vetített elő átfogó oktatási reformot, de még csak kiemelt figyelemmel sem kezelte az oktatási rendszert. Miközben az egészségügy reformjának külön fejezetet és viszonylag jelentős terjedelmet szentelt, addig az oktatáspolitikával csak érintőlegesen, a szakképzés problémái kapcsán foglalkozott.

A közoktatás területe nemcsak a kormányprogramban volt mellözött, hanem a Fidesznek a Nemzeti ügyek politikája címü - a kormányprogram alapjait meghatározó - választási programjában is. A közoktatás megújítása iránti igény talán leginkább a KDNP 2009-es „Iskola - erkölcs - tudás. A köznevelési, szakképzési, felsőoktatási és felnőttképzési rendszer újjáépítése" oktatáspolitikai tézisgyüjteményében fedezhető fel, de még ebből sem olvasható ki átfogó közoktatási reform ígérete. Az oktatási rendszer teljes körű reformjának szándékára sem a választási programok, sem pedig a kormányprogram alapján nem számíthattunk ${ }^{4} \mathrm{Ez}$ egyébként utólag azért is meglepő, mivel épp a 2010-es kormányváltással szüntették meg az önálló oktatási minisztériumot, és hozták létre több minisztérium összevonásával a Nemzeti Erőforrás Minisztériumot. Az oktatásügyi reform váratlan közpolitikai napirendre kerülése így nemcsak felkészületlenül érte az érintetteket, hanem - ahogyan az az alábbiakban látható lesz - egyszersmind lépéshátrányba is hozta őket az oktatásirányítással szemben (lásd például a tiltakozás fórumainak viszonylag késői megszerveződését).

Nem kétséges, hogy a magyar közoktatás megújításának szükségessége mellett több szakmai érv is szólt, vagy pontosabban szólhatott volna. A 2000-es évek végén több szakmai anyag is készült, amelyek érintették ezeket a problémákat (pl. Zöld könyv, Szárny és teher stb.). Ebben a cikkben nem célunk ezek tárgyalása, pusztán arra kívánunk rámutatni, hogy a 2010-ben hivatalba lépő új kormány oktatási reformot érintő kommunikációjában szinte egyáltalán nem jelentek meg szakmai érvek a közoktatás megújítása mellett. A kormányzati kommunikáció láthatóan nem törekedett arra, hogy kijelölje azokat a központi problémákat, amelyek kezelésére közpolitikai beavatkozást kezdeményezett. Hoffmann Rózsa, oktatásért felelős államtitkár ${ }^{5}$ a reform bejelentését követő nyilatkozataiból ugyanakkor jól körvonalazódik egy oktatáspolitikai paradigmaváltás kezdete. Az új ok-

4 Nem állapítható meg teljes bizonyossággal, hogy a közvélemény mikor értesülhetett első ízben az oktatási rendszer nagyszabású átalakításának programjáról. De az a sajtóból ismert, hogy a „Szárny és teher” címü, az oktatás megújításáról szóló javaslatcsomag megvitatására 2010. április 20-án rendezett konferencián Hoffman Rózsa (még államtitkárrá való kinevezését megelőzően) bejelentette: „hamarosan új, az oktatást érintö törvényeket szeretne a leendö kormányzat elfogadtatni az Országgyüléssel, és mintegy száz intézkedést terveznek bevezetni”. Lásd például: 24.hu, 2010. május 20. https://24.hu/belfold/2010/05/20/hogyan_ lesz_szarny_oktatas/ [Letöltve: 2018.10.31.]

5 Az új kormányzati struktúrában az oktatásirányítás fő intézményi szereplője az Emberi Erőforrások Minisztériumának Oktatási Államtitkársága. 
tatáspolitikai paradigmában a korábbi, 2002 és 2010 közötti időszakot jellemző integrációs paradigmával szemben - amit a kormányzati diskurzus gyakran az „elhibázott” jelzővel illet - az oktatásirányítás már nem tudományos érvekre építi legitimitását, hanem morális elvekkel és „a pedagógusszakma vélt nézőpontjával legitimálja” intézkedéseit (Neumann 2013: 161). Ezt jól szemléltetik az oktatásért felelős államtitkárnak az oktatásügy megújítását érintően adott interjúi. Álljon itt ezekből néhány részlet:

„Első lépésként újból meg kell erösiteni az iskola hagyományos nevelö szerepét, világos elvárásokat támasztva, szemben azzal a »szolgáltató « jelleggel, amivé az elmúlt nyolc év oktatásfilozófiája tette. Ennek részeként helyre kell állitani a tanárok tekintélyét is." ${ }^{6}$

"Nehéz lenne rangsorolni az elbibázott oktatáspolitikai intézkedések, a folyamatos pénzelvonás, a pedagógustársadalom ellenében hozott döntések miatt felhalmozódott bajokat. Arra vállalkoztam, hogy felemeljük a mélypontra süllyedt magyar oktatást... Ennek sok eleme van, például a nevelés visszahelyezése az oktatás egészébe, a pedagógusok tekintélyének helyreállitása. Első intézkedéseink között a bibás, de könnyen megváltoztatható elemek korrekciója mellett döntöttünk: ezek egyike az évismétlés és az osztályozás korábbi rendjének visszaállitása..."

„Lehet, hogy az emlitett új jogszabályok (megj:: itt a buktatásról és az érdemjeggyel való osztályozásról van szó) nem jelentenek gyökeres változást, de egyáltalán nem lényegtelenek, mert azt mutatják, hogy meg kell változnia az iskola belsö értékrendjének. A tényleges, nagy változásokra még várni kell legalább egy évet, vagy akár többet, biszen elö kell készíteni az új jogszabályokat: az új közoktatási törvényt, az új Nemzeti alaptantervet és a felsöoktatási törvényt." ${ }^{8}$

Egy későbbi, már a törvénytervezet kormány általi elfogadása (2011. augusztus 31.) után tartott rendezvényen az államtitkár úgy fogalmazott, hogy azért van szükség új törvényre és köznevelési rendszerre, mert a jelenleg hatályos törvényt még 1993-ban fogadták el, s azóta több mint száznegyvenszer módosították: „Ez mára toldozott-foldozott rubává vált, amelynek az egységessége réges-régen megbomlott". "Vagyis az oktatási rendszer reformjának szükségességét nem valamilyen társadalmi szükséglettel indokolta, hanem - hazai viszonylatban oly jellemző módon - jogi szemléletben (vö. Gajduschek-Hajnal 2010). Persze egy ilyen horderejü közpolitikai beavatkozást valószínúleg nehéz is lett volna létező társadalmi szükségletekre visszavezetni. Annál is inkább, mivel az oktatási rendszer ez idő tájt nem jelent meg problémaként a közvéleményben: az Eurobarometer felmérés adatai szerint 2009-ben és 2010-ben csak az állampolgárok elenyésző része (2-3\%-a) jelölte meg az oktatást az országot érintő két legfontosabb probléma között. ${ }^{10}$

Ahogyan a nagy horderejű változások általában, természetesen a közoktatás reformjának napirendre kerülése is bizonytalanságot keltett a reformok által érintettekben.

6 Evangelikus.hu, 2010. június 25. Nem akarunk tantervi diktatúrát - interjú Hoffmann Rózsával. https:// archiv.evangelikus.hu/lapszemle_2009-2011/nem-akarunk-tantervi-diktaturat-2013-interju-hoffmannrozsaval/?searchterm=None [Letöltve: 2018.10 .31 .]

7 Népszabadság, 2010. június 26. A középosztálynak és a leszakadóknak is kedveznünk kell. http://nol. hu/belfold/20100626-a_kozeposztalynak_es_a_leszakadoknak_is_kedveznunk_kell-716771 [Letöltve: 2018.10 .31 .]

8 24.hu, 2010. augusztus 17. Hoffmann Rózsa: keményebb munkára fogjuk a diákokat. https://24.hu/ belfold/2010/08/17/hoffmann_rozsa_kemenyebb_munkara_fogjuk/[Letöltve: 2018.10.31.]

9 szegedma.hu, 2011. szeptember 6. Hoffmann: föszabályként állami fenntartásba kerülnek az iskolák. https://szegedma.hu/2011/09/hoffmann-foszabalykent-allami-fenntartasba-kerulnek-az-iskolak [Letöltve: 2018. 10.31.]

10 A felmérésben arra kérdeznek rá, hogy mit tart a válaszadó az országot érintő két legfontosabb problémának. 
Az oktatásirányítás ugyanakkor nemhogy semmit nem tett annak érdekében, hogy az érintetteknek a status quo várható megbomlásából fakadó bizonytalanságát enyhíteni próbálja, hanem még hozzájárult annak fokozódásához. Kezdetben részint azzal, hogy a reform horderejéhez mérten szokatlanul rövid időt irányzott elö a közpolitikai beavatkozásra, részint pedig azzal, hogy nem állt elő világos és egyértelmü célokkal. A kormányzati kommunikációt tanulmányozva megfigyelhető, hogy abban a közpolitikai beavatkozás céljai helyett csak konkrét intézkedések szerepeltek. (Vö. Gajduschek-Hajnal 2010: 57.) A nyilatkozatok egyúttal azt is sejtetik, hogy ez idő tájt a célok maguk a döntéshozók előtt sem voltak világosak, a "hibás, de könnyen megváltoztatható elemek korrekcióján” túlra nagy valószínüséggel maguk sem láttak. Vagy ahogyan Radó (2014) egyik írásában megállapítja: úgy tünik, az oktatásirányítás a ciklus elején semmiféle koherens stratégiával nem rendelkezett. Egy kicsit más megközelítésben azt is mondhatnánk: a közpolitikai beavatkozással nem is valamilyen problémát kívántak megoldani, hanem a közoktatás rendszerével kapcsolatos beszédmód és közhangulat, vagyis a probléma társadalmi reprezentációjának átformálására törekedtek (vö. Rosen 2009; idézi Berényi 2016). Úgy kezdődött el tehát egy nagy horderejü közpolitikai reform, hogy arról a napirendre kerülése tájékán nem sokkal többet lehetett tudni, minthogy az a fennálló status quo radikális megváltoztatását eredményezi.

\section{A közoktatási törvény koncepciójának megalkotása}

Nézzük meg részleteiben is az új közoktatási törvény koncepciójának (a továbbiakban: koncepció) kidolgozását, illetve annak körülményeit! Ahogyan az a sajtóban több ízben is megjelent, a koncepció készítése a nyilvánosságot kizárva, meg nem nevezett szakértőkkel folyt. ${ }^{11} \mathrm{Az}$ oktatásért felelős államtitkár a vele készített interjúkban rendre megkerülte azokat a kérdéseket, amelyek a koncepció készítőinek kilétére vonatkoztak, és a neveket egy hírportál külön kérésére sem adták ki. ${ }^{12}$ A sajtóban ugyanakkor napvilágot látott, hogy a bevont pedagógusok, szakemberek szinte kizárólag egyházi iskolai hátterüek voltak. A nyilvánosság kerülése mellett így az is gyengítette a reform iránti bizalmat, hogy a Hoffmann-bizottságokba csak a szakmabeliek egy szük, ideológiai alapon rekrutált körét hívták meg. Emellett, ahogyan - a szintén a nyilvánosságtól elzártan készülő felsőoktatási koncepcióval összefüggésben - Polónyi István (2011) rámutatott: a nyilvánosság kizárása a koncepciót megalapozó munka hiányát is jelezte.

Hamar világossá vált az is, hogy az államtitkárság csak a kész koncepció részleteit illetően kíván társadalmi egyeztetést kezdeményezni, stratégiai kérdésekben nem. ${ }^{13} \mathrm{~A}$ koncepció egy változata 2010 novemberében kiszivárgott, aminek kapcsán az államtitkár így nyilatkozott: „A mikor majd a miniszteri értekezlet jóváhagyja a tervezetet, sajtótájékoztatón

11 Erről lásd pl.: hvg.hu, 2016. december 19. „Hagyjuk a számokat, Zolikám!” - Ötéves Hoffmann Rózsa jövőellenes müve. https://hvg.hu/itthon/20161219_ot_eves_hoffmann_rozsa_kozoktatasi_torveny_ pokorni_zoltan_pisafelmeres_oktatas_iskola [Letöltve: 2018.10.31.]

12 Lásd pl.: 24.hu, 2010. szeptember 7. Nemzeti együttműködés a Fidesz nélkül. https://24.hu/ belfold/2010/09/07/nemzeti_egyuttmukodes_fidesz_nelkul/ [Letöltve: 2018. 10. 31.]

13 Jól tetten érhető ebben az a hazai felfogás, amelyben a közpolitika-alkotás mint jogalkotási folyamat tételeződik (erről lásd Gajduschek-Hajnal 2010). 
bozzuk nyilvánosságra. Addig nem kívánunk sem nyilatkozni, sem vitatkozni a közoktatási törvényröl. Az érdemi vita ugyanis csak a végleges anyagról kezdödhet."14

A nyilvánosság kirekesztése a közpolitikai ciklus későbbi szakaszában is folytatódott. 2011. október végén megjelent a sajtóban, hogy a kormány által elfogadott köznevelési törvényhez kapcsolódik egy nem nyilvános, 40 oldalas háttértanulmány, amely többek között pedagóguselbocsátásokat, a tanárok munkaterhének növelését, iskolabezárásokat vetített előre. ${ }^{15} \mathrm{~A} z$ oktatási államtitkár először közleményben cáfolta, hogy létezne ilyen dokumentum. Később helyettese egy oktatásbizottsági ülésen kénytelenkelletlen elismerte a létezését, beleértve az abban foglalt - az Ecostat által készített prognózist is. ${ }^{16}$

A közoktatási reform váratlan közpolitikai napirendre kerülése által okozott bizonytalanságot a bizalmat gyengítő lépések sora követte: a színfalak mögött, a nyilvánosságot kizárva készülő koncepció, a célok körüli bizonytalanság, az előkészítetlenségre és átgondolatlanságra utaló jelek, a társadalmi egyeztetésnek a kész koncepció véleményezésére való szűkítése, majd végül az a sikertelen - és a döntéshozók szavahihetőségét erősen megkérdőjelező - próbálkozás, amellyel az államtitkár a reform várható hatásait igyekezett az érintettek elől eltitkolni. Márpedig, ahogyan fentebb is említettük, nem várható az érintettek részéről a bizalom megelőlegezése, amennyiben a döntéshozók nem tisztáznak olyan érzékeny kérdéseket, mint amilyenek a reformok elosztási hatásai (OECD 2015: 155). Azt mondhatjuk tehát, hogy a közpolitikai folyamat a bizalmat megalapozó mindkét elem, tehát a kompetencia felmutatása és a méltányos eljárás mint a közjó képviselete tekintetében is gyengén teljesített.

\section{A társadalmi szereplök reakciói és a törvény elfogadása}

A közoktatási reform társadalmi egyeztetésének megvalósulását illetően élesen eltér az oktatásirányítás és a reform által érintett különböző érdekcsoportok megítélése. Az oktatási államtitkárság szerint a reform terveit komoly szakmai egyeztetés előzte meg. Egy 2011-es interjúban az államtitkár így nyilatkozott ezzel összefüggésben: „Nevéböl adódóan a koncepció elsö verzióját vitairatnak szántuk, és mivel valós konzultációra törekedtünk, ezért az alapelgondolásainkkal megegyezö, pontositó, megfontolásra érdemes szakmai javaslatok jelentös részét beépitettük a tervezetbe."17

A Budapest Intézet stakeholder-kutatása (2013) - melynek keretében 2012. december és 2013. február között 27 interjú készült ${ }^{18}$ - ugyanakkor azt találta, hogy 2010 és 2013 között az érdekelteket nem vonták be a döntéshozatalba, vagy ezt legfeljebb csak lát-

14 nemzetiforum.hu, 2010. november 22. „Még kézzelfogható volt az ellenséges hangulat” - interjú Hoffmann Rózsával. http://www.nemzetiforum.hu/index.php?id=meg-kezzelfoghato-volt-az-ellensegeshangulat-interju-hoffmann-rozsaval [Letöltve: 2018. 10.31.]

15 24.hu, 2011. október 27. A Hoffmann-terv titkos részei. https://24.hu/belfold/2011/10/27/a-hoffmannterv-titkos-reszei/ [Letöltve: 2018. 10.31.]

16 24.hu, 2011. november 5. Beismerték Hoffmann hazugságát. https://24.hu/belfold/2011/11/05/ beismertek-hoffmann-hazugsagat/ [Letöltve: 2018. 10.31.]

17 eduline.hu, 2011. április 6. „A lógást nem fogja finanszírozni az állam” - interjú Hoffmann Rózsával. http://eduline.hu/felsooktatas/2011/4/6/20110405_hoffmann_rozsa_felsooktatas_interju [Letöltve: 2018. 10. 31.]

18 Az interjúalanyokat a kutatásban úgy választották ki, hogy azok az oktatáspolitikai stakeholderek minél több csoportját lefedjék (a pedagógusok csoportján kívül). 
szatra tették. Ebben azonos állásponton voltak a reformot ellenző és az azt támogató stakebolderek is. Érdemes azt is megjegyezni, hogy a fentebbi interjúrészlet - még ha nem is szándékoltan - maga is sejteti, hogy az oktatásirányítás felfogásában a konzultáció valójában nem több mint a szakmai lektorálásban való részvétel lehetősége.

$\mathrm{A} z$ intézményvezetők látszatbevonását jól példázza az a - tudományos megalapozottságot teljesen nélkülöző - kérdőíves felmérés is, melyet az oktatásirányítás végzett 2011 tavaszán a közoktatási intézmények vezetőinek körében a reform intézkedéseivel összefüggésben, és amelynek keretében az intézményvezetőknek másfél nap állt a rendelkezésükre, hogy emailben válaszoljanak a kérdésekre. A „konzultációnak” ezt a módját kifogással illették a pedagógusok szakszervezetei, és az öt ágazati szakszervezet a valódi egyeztetések kikényszerítésére közös demonstrációt helyezett kilátásba. ${ }^{19}$ Ezt követően, 2011. május végén sor került egy egyeztetésre az államtitkár és a PSZ elnöke között, de Galló Istvánné a konzultációt követően is úgy vélte, hivatalos egyeztetés és nyilvánosságra hozott dokumentumok híján a tanárok bizonytalanságban élnek, ezért a tüntetést nem fújták le. ${ }^{20}$

2011. október 12-én a kormány nyilvánosságra hozta a nemzeti köznevelésről szóló törvény véglegesnek szánt szövegét, melyet október 25 -ig lehetett véleményezni. Egy nappal rá lemondott az Országos Köznevelési Tanács (OKNT) elnöke. Távozását - tartalmi okok mellett - azzal indokolta, hogy a törvény szövegváltozata előbb került a nyilvánosság, mint az OKNT elé, vagyis a tanács nem élhetett a - még hatályos közoktatási törvényben biztosított - véleményezési jogával. ${ }^{21}(\mathrm{~A} z$ akkor még hatályos korábbi közoktatási törvény értelmében az OKNT a közoktatásért felelős miniszter legfőbb tanácsadó és konzultatív testülete.)

Jól jelzi a társadalmi párbeszéd intézményi kereteinek lebontását, hogy - szemben a korábbi közoktatási törvénnyel, amely részletesen szólt az OKNT és a Közoktatáspolitikai Tanács (KT) összetételéről és feladatairól - az új köznevelési törvénybe egyetlen ilyen szövegrész sem került be (Bajomi-Csákó 2017: 530). A törvény elfogadásával egy időben megszünt a Közoktatás-politikai Tanács, és a közvélemény számára láthatatlanná vált az OKNT (ibid. 531). A kormány lényegében mindhárom alapvető konzultációs mechanizmust felszámolta: a különböző érdekcsoportokkal folytatott konzultációt, a szakmai szervezetekkel folytatott konzultációt és a szakszervezetekkel folytatott tripartit érdekegyeztetést (Radó 2014). A konzultációs mechanizmusok leépítése egyúttal a nyilvánosságot is kiszürte az oktatáspolitika gyakorlatból (Radó 2014).

Ebben az időszakban több civil szerveződés is létrejött, hogy a törvénytervezet elleni tiltakozását kifejezze. Közülük is kiemelendő, hogy 2011 novemberében - pedagógusok, egyetemi oktatók, kutatók, szülők, tanulók részvételével - megalakult a Hálózat a Tanszabadságért (HAT) nevű társaság, mely alapító nyilatkozatában leszögezi: „elfogad-

19 hvg.hu, 2011. május 11. Röpdolgozat. https://hvg.hu/hetilap/2011.19/201119_ropdolgozat [Letöltve: 2018. 10.31.]

20 eduline.hu, 2011. május 30. Visszavonulót fújt Hoffmann: egyeztettek a Pedagógusok Szakszervezetével. http://eduline.hu/kozoktatas/2011/5/30/20110530_pedagogusok_szakszervezete_egyeztetes\#utm_ source $=$ hirkereso\&utm_medium $=$ listing\&utm_campaign=hirkereso_2011_5_30 [Letöltve: 2018. 10. 31.]

21 Magyar Narancs, 2011. október 20. A pedagógia válasza - Loránd Ferenc, az Országos Köznevelési Tanács lemondott elnöke. https://m.magyarnarancs.hu/belpol/a_pedagogia_valasza___lorand_ferenc_az_ orszagos_koznevelesi_tanacs_lemondott_elnoke-77143 [Letöltve: 2018.10.31.] 
batatlannak tartjuk azt, amilyen tartalommal és amilyen eljárásban - a szakmai, a szakmai érdekképviseleti és civil vélemények, valamint az elözetesen bejelentett véleményezési határidök figyelmen kivüll hagyásával - a nemzeti köznevelésröl szóló törvény tervezetét elökészitették". ${ }^{2}$ Tanulságos, ahogyan egy szülőket tömörítő csoport, a Szülői Hálózat alapítója egy interjúban összefoglalta az érdekképviselet lehetőségeit: „Nem tudhattuk, hogy az államtitkárság, meg sem várva a szakmai vélemények beérkezésének határidejét, már keresztülveri a kormányülésen a tervezetet. Nekünk, írd és mondd, összesen volt búsz napunk arra, hogy 1. megalakuljunk, 2. eldöntsük, hogy reagálunk az eseményekre, 3. kitaláljuk a reakciók mikéntjét, 4. megszervezzük az eseményeket." ${ }^{3}$

A z érintett csoportok reakciói egyrészt világosan jelzik a közoktatási változtatások iránti bizalmatlanságukat, másrészt logikus következményei ennek: a bizalom hiányában megvonták támogatásukat a reformtól, és aktívan tiltakoztak ellene.

\section{A közoktatási reform megvalósitása}

A bizalom mint legitimációs indikátor előre jelzi a döntések végrehajtásának támogatottságát és az abban való együttműködésre való hajlandóságot is (Boda 2016). Láttuk ugyanakkor, hogy a közoktatási törvény 2011. decemberi elfogadásáig az oktatásirányítás iránti bizalom az érdekeltek szinte minden csoportjában megingott. Ebben a bizalomhiányos környezetben kezdődhetett meg az új köznevelési törvény implementációja. Ahogyan azt borítékolni is lehetett, a megvalósítás több szempontból is a lehetséges határait feszegette. Ennek egyik nyilvánvaló oka az oktatási rendszert érintő intézkedések példátlanul nagy száma volt. Radó (2014) szerint 2013-ban az oktatási szektorban több mint negyven rendszerszintü változtatást indítottak el, miközben „egy jól szervezett, bejáratódott politika koordinációs és konzultációs mechanizmusokat müködtető, az implementációt jól szolgáló professzionális intézményrendszerrel rendelkező kormányzat - ha birtokában van a szükséges pénzügyi erőforrásoknak - két-három nagyobb szabású rendszerszintű változtatást képes menedzselni”. Ezek a feltételek azonban Magyarországon távolról sem voltak biztosítva. Egyfelől, a példátlan mennyiségű változás részleteiben nem volt kidolgozva, megvalósításuk módja sem volt kitalálva, illetve nem történtek meg az ahhoz szükséges előkészületek. Másfelől, nem álltak rendelkezésre a végrehajtáshoz szükséges pénzügyi források sem. Ezt jól jelzi, hogy 2012 októberében a közoktatás átalakításához szükséges pénzügyi háttér hiányára hivatkozva felmentését kérte a közoktatási helyettes államtitkár (amit az emberi erőforrások minisztere nem fogadott el, így arra csak hónapokkal később kerülhetett sor). „Az ország jelenlegi állapotában alázattal kell azonban tudomásul vennem, hogy a köznevelési rendszer átalakitásának financiális háttere, amely természetesen nem egyszerüen pedagógusbér-emelést jelent, egyelöre nem áll rendelkezésre. Mindez ebben a pillanatban egyúttal az általunk elökészitett oktatási reformok bevezetbetőségét is megkérdöjelezi" - áll a helyettes államtitkár lemondásának írásos indoklásában. ${ }^{24}$ Harmadrészt, az is nyilvánvaló, hogy "jól szervezett, bejáratódott politika koordinációs és konzultációs mechanizmusokat működtető" kormány-

22 http://www.tanszabadsag.hu/blog/alapito-nyilatkozat-teljes/ [Letöltve: 2018. 10. 31.]

23 koloknet.hu, 2011. december 9. „Fogadóóra” a Kossuth téren. http://m.koloknet.hu/iskola/pedagogus/ oktataspolitika/fogadoora-a-kossuth-teren/ [Letöltve: 2018. 10.31.]

24 Népszabadság, 2012. október 18. Lemondott Gloviczki Zoltán, főnöke, Hoffmann Rózsa marad. http:// nol.hu/belfold/20121018-berharc_jon__gloviczki_megy-1340269 [Letöltve: 2018. 10. 31.] 
zatról sem beszélhetünk. Jól példázza ezt, hogy 2012. október 19-én - az Országos Közszolgálati Érdekegyeztető Tanács (OKÉT) ülését követően - sztrájkbizottságot alakítottak a közoktatásban müködő ágazati szakszervezetek. A lépést a tanári béremelések 2013 szeptemberéről 2014 januárjára halasztása, és az ezzel párhuzamosan megemelt kötelező óraszámmal indokolták. A Pedagógusok Demokratikus Szakszervezetének (PDSZ) elnöke azt a követelést fogalmazta meg, hogy „január 1-jétöl 20 százalékkal emeljék a közszféra minden dolgozójának bérét, illetve függesszék fel az iskolák január 1-jétöl tervezett állami átvételét". Egyúttal arra is felszólította a kormányzatot, hogy ne hozzanak olyan döntéseket, amelyeket nem egyeztettek minden oldallal, „nemcsak a hozzájuk közel álló szakmai szervezetekkel [...], banem hallgassák meg [...] azoknak a véleményét is, akiknek esetleg az általuk elöterjesztettel szemben ellenkezö véleményük van”. A PSZ elnöke arra mutatott rá, hogy „a közoktatás átalakitásának nem csak a pedagógusok lesznek a szenvedő alanyai, a következmények a gyerekeket és a szülöket is hátrányosan fogják érinteni. ${ }^{25} \mathrm{~A}$ helyzet eszkalálódásában szerepet játszott az a körülmény, hogy egy kormánydokumentum tanúsága szerint maga a kormány ajánlotta fel az EU-nak a béremelésekkel is járó pedagógus-életpályamodell 2014-re halasztását, miközben az oktatásirányítás továbbra is hitegette a tanárokat annak 2013-as bevezetésével. A fenti interjúrészletek az oktatásirányításba vetett bizalom olyan fokú eróziójáról árulkodnak, amely már önmagában is veszélyt jelent a reform megvalósítására.

A cikkben nem tekintjük célunknak a közoktatási reform implementációjának végigkísérését, így a továbbiakban csak egy-két olyan sajátosságot emelünk ki, ami már a folyamat kezdeti szakaszában is megfigyelhető volt. A megvalósítás során jellemző volt az intézkedések elhalasztott végrehajtása, a feltételek tekintetében kompromisszumokkal terhelt végrehajtás (illetve kiskapuk biztosítása), de ugyanígy az utólagos korrekció, kiigazítás is. Az elhalasztott végrehajtásra példa a már említett pedagógusbér-emelés mellett a hároméves kortól kötelező óvodáztatás bevezetése, ami a megfelelő feltételek híján 2014 ősz helyett csak egy évvel később léphetett hatályba. Kompromisszumos volt a mindennapos testnevelés felmentő rendszerben történő bevezetése, miután az iskolák jelentős részében a megfelelö infrastrukturális feltételek hiánya miatt iskolai folyosókon vagy az utcán tartott testnevelésórákban valósult meg. 2013 májusában aztán jött egy kiskapu a mindennapos testnevelés elkerülésére. Végül, az utólagos korrekciókat és kiigazításokat jól példázza az iskolák államosítása. Ez csak később került be a közoktatási reform intézkedései közé (2012-ben szavazták meg), és miután hamarosan bebizonyosodott a müködésképtelensége, 2016-ban már be is jelentették a centralizáció mértékét némileg csökkentő terveket. Már ez a néhány példa is jól illusztrálja, hogy az oktatásirányítás számos esetben kényszerült az intézkedések módosítására vagy visszavonására, ami kérdésessé tette, hogy birtokában van a reform lebonyolításához szükséges kompetenciáknak.

$\mathrm{A} z$ átalakuló közoktatási rendszer iránti bizalom eróziója mára egyre nyilvánvalóbb módon látszik. Az implementáció kezdete óta eltelt utóbbi években ezt már korántsem csak az oktatási rendszerrel kapcsolatos folyamatos megmozdulások, tiltakozások jelzik, amilyen például a miskolci Herman Ottó Gimnázium tanárainak nyílt levele nyomán kibontakozott tanármozgalom. ${ }^{26} \mathrm{~A} z$ állami oktatási rendszerrel való egyre fokozódó elége-

25 Pedagógusok lapja, 2012/11. Megalakult a sztrájkbizottság, a pedagógusoknak elegük lett. https://www. pedagogusok.hu/userfiles/letoltheto_szamok/PL-2012-11.pdf [Letöltve: 2018. 10. 31.]

26 Ezekről lásd Bajomi-Csákó 2017. 
detlenséget újabban már a kritikus méreteket öltő - mára több mint 4 ezer fós - pedagógushiány is visszatükrözi. Emellett annak is vannak egyértelmű jelei, hogy a szülők egyre nagyobb számban viszik gyerekeiket magán- vagy alapítványi iskolákba. Az Alapítványi és Magániskolák Egyesületének elnöke szerint sok szülő egyszerűen azért vált, mert a központi kerettanterv kötelező jellegével és minőségével nem ért egyet. ${ }^{27}$ (Az alternatív tanrenddel müködő iskoláknak ugyanis törvény adta joguk van arra, hogy a központi kerettantervtől eltérően oktassák a gyerekeket.) Ezek az újabban megfigyelhető jelenségek - szemben a korábbi tiltakozó megmozdulásokkal - már a "kivonulás” stratégiájának a megnyilvánulásai (vö. Hirschman 1995).

\section{Az oktatási színvonal állampolgári megítélése}

A bizalom csökkenésével párhuzamosan - nem meglepő módon - romlott az oktatás színvonalának állampolgári megítélése is, amint azt például a TÁRKI felmérései is mutatják. Míg 2009-ben a megkérdezettek 11\%-a szerint volt rossz vagy nagyon rossz az oktatás színvonala, addig 2012-ben ez az arány 20\%-ra emelkedett. Ezzel szemben az oktatás minőségét közepesre értékelők aránya 53\%-ról 44\%-ra csökkent, a színvonalat jónak vagy nagyon jónak tartók tábora pedig ugyanakkora maradt (Lannert 2012). Látható, hogy az oktatás minőségének megítélése már a reform elfogadását követően, de még az implementáció folyamatát megelőzően kedvezőtlenebbé vált. Noha erre vonatkozóan újabb adatok nem állnak rendelkezésünkre, más felmérések alapján a vélemények további romlását valószínűsíthetjük. Az Eurobarometer újabb hullámai például arról árulkodnak, hogy az oktatási rendszer egyre több állampolgár szemében jelenik meg mint megoldásra váró probléma. A kérdőív fentebb már idézett kérdésére adott válaszokból egyértelmüen látszik, hogy 2014-től kezdődően felmérésről felmérésre ${ }^{28}$ nőtt azoknak az aránya, akik az oktatási rendszert a két legfontosabb probléma között említik, amellyel az ország jelenleg szembenéz (az adatsorban 2016-ban ugrik meg ez az arány). Miközben - ahogy fentebb már utaltunk rá - 2009-10-ben még a kérdezettek 2-3\%-a választotta be az oktatást a legfontosabb problémák közé, addig 2018-ban már 13\%-uk.

Az oktatási rendszerrel kapcsolatos állampolgári vélemények kedvezőtlen alakulása egyébként egybecseng azzal, amit a közoktatás minőségét leíró objektív mutatók (mint például a középfokú oktatásból lemorzsolódott tanulók aránya), vagy az OECD PISA felmérésének adatai jeleznek. Ezeknek a részletes bemutatásával e cikk keretei között nem áll módunkban foglalkozni, ám azt megemlítjük, hogy a 15 éves tanulók teljesítménypontszámai egyértelműen romló tendenciát mutatnak. Ez ugyan már 2009-től kezdve megfigyelhető volt mindhárom tárgyból, de a további esés következtében szövegértésből és természettudományból a teljesítménypontszámok 2015-ben ütötték meg az eddigi legalacsonyabb szintet (matematikából ez már korábban, 2012-ben bekövetkezett).

27 https://index.hu/belfold/2015/11/25/nem_kell_nekik_az_allami_iskola/ [Letöltve: 2018. 10. 31.]

28 A felmérést többnyire évente kétszer végzik. 


\section{Összegzés}

Ahogyan fentebb láttuk, az oktatási rendszer iránti bizalom a közoktatási reform elfogadását követően - a GWP adatai szerint 2012-től - erősen gyengülni látszik, ami megmutatkozik részint a különböző érdekelt csoportok tiltakozásában, részint pedig az utóbbi időket tekintve bizonyos, kivonulásként értelmezhető jelenségekben is (lásd pl. alternatív iskolák választása, tanárhiány). A bizalom eróziójához hozzájárulhatott a rendszer megújítását célzó közpolitikai folyamat maga - miután annak során megkérdőjeleződött mind az eljárás méltányossága, mind pedig a közpolitikai szereplők kompetenciája. Az eljárás méltányossága már a közpolitikai folyamat elején kérdésessé vált azzal, hogy az oktatásirányítás láthatólag nem törekedett a reformmal kapcsolatos bizonytalanság csökkentésére, a közpolitikai folyamat átláthatóságának megteremtésére (beleértve a várható hatások körüli titkolózást) és az érdekeltek részvételének előmozdítására. A közpolitikai aktorok kompetenciája iránti bizalmat gyengíthette a célok világos megjelölésének hiánya, ami egyúttal az átgondolatlanság és előkészítetlenség képzetét kelthette $a z$ érdekeltekben. Az oktatásirányítás kompetenciája iránti bizalmat mindazonáltal az implementáció anomáliái (lásd pl. kiskapuk, korrekciók) kezdhették ki legerőteljesebben. Végül, a bizalomvesztésben a közpolitikai folyamat mellett szerepet játszhatott a közoktatás színvonalának (mint a közpolitikai folyamat kimenetének) kedvezőtlenebbé váló állampolgári megítélése is.

\section{IRODALOM}

Вајомі I. \& Csákó M. (2017) Fórumok és tiltakozómozgalmak a közoktatásban. Educatio, Vol. 26. No. 4. pp. 528-539.

Barber, B. (1983) The Logic and Limit of Trust. New Jersey, Rutgers University Press.

Berény E. (2016) Az autonómiától a szelekcióig. A közpolitika mint a szociológia tárgya. Iskolakultúra, Vol. 26. No. 9. pp. 3-22.

Boda Zs. (2013) Legitimitás, bizalom, együttmüködés: kollektív cselekvés a politikában. Budapest, Argumentum.

Boda Zs. (2016) Intézményi bizalom és a közpolitikák eredményessége. In: Boda Zs. (ed.) Bizalom és közpolitka. Jobban müködnek-e az intézmények, ba biznak bennük? Budapest, Argumentum - MTA TK PTI. pp. 7-23.

Bouckaert, G. (2012) Trust and Public Administration. Administration, Vol. 60. No. 1. pp. 91-115.

Budapest Intézet (2013) Jelentés az Oktatáspolitikai Stakeholder-kutatásról. Budapest, 2016. március 6.

Cerna, L. (2014) Trust: What It is and Why It Matters for Governance and Education. OECD Education Working Papers, No. 108. OECD Publishing.

Dasgupta, P. (1988) Trust as a Commodity. In: D. Gambetta (ed.) Trust. Making and Breaking Cooperative Relations. New York, Basil Blackwell. pp. 49-72.

Fazekas, M. \& Burns, T. (2012) Exploring the Complex Interaction between Governance and Knowledge in Education. OECD Education Working Papers, No. 67. OECD Publishing, Paris. 
Ford, J. \& Ford, L. (1995) The Role of Conversations in Producing Intentional Change in Organisations. The Academy of Management Review, Vol. 20. No. 3.pp. 541-570.

Gajduschex Gy. \& Hajnal Gy. (2010) Közpolitika. A gyakorlat elmélete és az elmélet gyakorlata. Budapest, HVG-ORAC Lap- és Könyvkiadó Kft.

Gambetta, D. (1988) Can We Trust Trust? In: D. Gambetta (ed.) Trust. Making and Breaking Cooperative Relations. New York, Basil Blackwell. pp. 213-237.

Győrffy D. (2012) Institutional Trust and Economic Policy: Lessons from the History of the Euro. Budapest, Central European University Press.

Halász G. (2006) Az oktatás kormányzásának jövője: válasz a komplexitás kibivására. http:// halaszg.ofi.hu/download/Hiroshima.pdf [Letöltve: 2018. 10. 31.]

Hetherington, M. (2005) Why Trust Matters: Declining Political Trust and the Demise of American Liberalism. Princeton (NJ), Princeton University Press.

Hirschman, A. O. (1995) Kivonulás, tiltakozás, büség. Budapest, Osiris.

LANNERT J. (2012) TÁRKI-közvéleménykutatás az oktatás területén a lakosság és a pedagógusok körében. (a 2012 decemberében végzett adatfelvétel elemzése).

Lummann, N. (1988) Familiarity, Confidence, Trust: Problems and Alternatives. In: D. Gambetta (ed.) Trust. Making and Breaking Cooperative Relations. New York-Oxford, Basil Blackwell. pp. 94-107.

Nemzeti Együttmúködés (2010) A Nemzeti Együttmúködés Programja - munka, otthon, család, egészség, rend.

Neumann E. (2013) Politika a padsorok között. In: Berényi, E., Erőss G. \& Neumann E. (eds), Tudás és politika. A közpolitika-alkotás gyakorlata. Budapest, L'Harmattan.

OECD (2013) Trust in Government. Assessing the Evidence, Understanding the Policies. 47th Session of the Public Governance Committee. 25-26 April 2013. OECD Conference Centre Paris, France.

OECD (2013a): Government at a Glance 2013. Paris, OECD Publishing.

OECD (2016) Education Governance in Action: Lessons from Case Studies. Paris, OECD Publishing.

Polóny I. (2011) Szép új világ a felsőoktatásban? https://hazaeshaladas.blog. hu/2011/10/27/szep_uj_vilag_a_felsooktatasban [Letöltve: 2018. 10.31.]

Puranam, P. \& Vanneste, B. (2009) Trust and Governance: Untangling a Tangled Web. Academy of Management Review, Vol. 34. No. 1. pp. 11-31.

Radó P. (2014) A nemzeti együttműködés közoktatási rendszere és a PISA mérések. Beszélö Online 2014. február 3. http://beszelo.c3.hu/onlinecikk/a-nemzeti-egyuttmukodeskozoktatasi-rendszere-es-a-pisa-meresek [Letöltve: 2018. 10. 31.]

Rosen, L. (2009) Rhetoric and Symbolic Action in the Policy Process. In: G. Sykes, B. Schneider \& D. N. Plank (eds) Handbook of Educational Policy Research. New York, Routledge. pp. 267-285.

Smith, K. B., Larimer, C. W., Littvay, L. \& Hibbing, J. R. (2007) Evolutionary Theory and Political Leadership: Why Certain People Do Not Trust Decision Makers. The Journal of Politics, Vol. 69. No. 2. pp. 285-299.

Snyder, S. (2013) The Simple, the Complicated, and the Complex: Educational Reform Through the Lens of Complexity Theory. OECD Education Working Papers, No. 96. OECD Publishing, Paris.

Szárny és teher (2009) Szárny és teher. A magyar oktatás helyzetének elemzése. Háttéranyag.

Széll Kálmán Terv - Összefogás az adósság ellen, 2011. március 1. 
Tyler, T. R. (1990) Why People Obey the Law. New Haven, Yale University Press.

VAn der Schee, E. et al. (2007) Public Trust in Health Care: A Comparison of Germany, the Netherlands, and England and Wales. Health Policy, Vol. 81. No. 1. pp. 56-67.

Warren, M. (1999) Democratic Theory and Trust. In: M. Warren (ed.) Democracy and Trust. Cambridge, Cambridge University Press. pp. 310-345.

Zöld könyv (2008) Zöld könyv: A magyar közoktatás megújításáért. FazeKas K., KöLlő J. \& VARGA J. (eds) Budapest, ECOSTAT.

A cikk a Creative Commons Attribution 4.0 International License (https://creativecommons.org/licenses/ by/4.0/) feltételei szerint publikált Open Access közlemény, melynek szellemében a cikk bármilyen médiumban szabadon felhasználható, megosztható és újraközölhető, feltéve, hogy az eredeti szerző és a közlés helye, illetve a CC License linkje és az esetlegesen végrehajtott módosítások feltüntetésre kerülnek. (SID_1) 